\title{
Is It Rational to Order Ships When Freight Markets Are in Depression?
}

\author{
Alexandros M. Goulielmos (Corresponding author) \\ Professor Emeritus Of Marine Economics \\ University Of Piraeus, Department Of Maritime Studies \\ 85 Karaoli And Dimitriou St., Piraeus 18534, Greece \\ E-mail: Am.Goulielmos@Hotmail.Com;Ag@Unipi.Gr
}

Received: June 26, 2014 Accepted: August 7, 2014 Published: September 15, 2014

doi:10.5296/ijssr.v2i2.6315 URL: http://dx.doi.org/10.5296/ijssr.v2i2.6315

\begin{abstract}
"Very high spot rates induce excessive orders" this statement is tested. Time charter rates found not only to influence orders more than spot rates, but so does the price of shipbuilding. It is also shown that the surplus of supply over demand is a more accurate measure for shipowners in placing orders. This was first proposed by Koopmans (1939), but never tested statistically till this paper.

Shipowners only remember well a depression that occurred in their lifie-time. They order ships during a depression to secure low prices, embody new technology (e.g. energy saving ECO ships) or invest in promising ships (e.g. LNG, offshore units and large containerships).

Some orders are placed at low freight rates. This phenomenon was first described by Zannetos (1966) (the "Zannetos' paradox"). This paradox, however, contradicts maritime economists' assumption of perfect foresight and a normal distribution for market disturbances. We take into account that a depression reduces capital cost (due to the lower new-building prices) and at the same time obliges shipowners to reduce operating costs. The previous boom (2003-2008) greatly helped subsequent orders in 2009-2014, as owners have built up sufficient liquidity.

A depression is a period when, historically, shipowners have committed serious errors. It is rational to order ships when freight rates are high, but is it not suicidal to order them when spot, or time charter, rates, produce great losses? This is cleared out.
\end{abstract}

Key-words: Rates and orders, 1999-2013, Zannetos' paradox, Koopmans' theory, economic depression 


\section{Introduction}

During the first 8 months of 2013 - the fifth year of the latest depression - a million dwts of Capes $^{1}$ were ordered. Moreover, crude tankers ordered reached $41 \%$ of the existing fleet in 2006-2007 (1,500 units) and 11\% at the end of October 2013 (500 units, on a 337m dwt world fleet). The fleet size reduced continuously after $2008^{2}$. When ordered ships are delivered, oversupply is naturally created if demand remains constant. During a boom, a waiting process for berth and construction sets in. In a depression, owners try to retard all processes; deliveries are postponed, orders are cancelled - if possible (even at high cost) slow-steaming is applied, and ships are sold or laid-up or scrapped. A depression makes the Alpha $^{3}$ coefficient move closer to one than two. A depression proves that billions of dollars of past investment were unjustified ${ }^{4}$. The drama of being a shipowner starts.

Examining the current situation, 2009 created a fall of $5 \%$ in seaborne trade ${ }^{5}$. In comparison, the 1981-1987 depression produced four (1980-1983) consecutive yearly reductions. For this reason, the 1981-1987 depression was prolonged and deep. Oil demand fell by only $3.5 \%$ in 2004 and $1 \%$ in 2009 and a further $1.1 \%$ at the end of 2013. This was followed by a fall in world GDP, from plus 5\% in 2007 to $3.4 \%$ at the end of 2013 .

A maritime depression is frequently caused, or intensified, by over-ordering. An independent observer may ask, with some justification, "Do shipowners remember past depressions and the way they were created?" If they do, they should avoid over-ordering, which, time after time, led them to depressions.

Two contemporary depressions occurred in 1981-1987 (for dry cargo) and 1979-1987 (for tankers) and at the end of 2008. Moreover, the current depression reminds us of 1929-1937 (Black Tuesday $^{6}$ ). The depression at the end of 2008, however, will not last six years like the two previous ones ${ }^{7}$. The current depression, we believe, is here to stay.

Each shipping company decides its orders independently. Some companies also build new ships and charter them with first class charterers over the long term. Nowadays, shipowners know the number of ships on order, thanks to the maritime information revolution. This was

\footnotetext{
${ }^{1}$ Capes transport iron-ore from Brazil and Australia; coal from Australia and S Africa; they are too wide to transit Panama Canal (pass round Cape). In 2009 a Cape varied from 170k to 180k. They serve the markets of China and India. In 2007 (July) Capes were 126 million dwt, 1/3 of total dry bulk (Stopford, 2009).

2 Kanellopoulou F, 13 ${ }^{\text {th }}$ 'Mare Forum Shipfinance conference', 22nd Oct. 2013.

3 Alpha indicates how peaky a distribution is and how fat tails are. Fat tails permit more frequent extreme outcomes and risk [(alpha $<2)$; alpha $=2$ for a normal distribution)].

${ }^{4}$ Scarsi (2007) asked herself why shipowners dispose ships at the bottom of the market. Are they inexpert investors? Stopford (2009) noted that distressed ship sales during the 1981-1987 depression were due to cash flow pressures.

5 Falls in seaborne trade occurred in: 1975 (-7.5\%), 1980-1983 (-3\%, -4\%, -8\%, -1\%), and in $1985(-1 \%)$ (Valentine et al., 2013).

${ }^{6}$ October $29^{\text {th }}, 1929$, date of a stock market crash.

7 Goulielmos (2013b)
} 
impossible before $1976^{8}$. So, over-ordering today cannot be blamed on the lack of data ${ }^{9}$ as it was in the past.

However, there is no coincidence of shipping investment theory and practice. Some think shipowners do well with their investment decisions, while others disagree, and suggest that the shipping industry has not learned from history ${ }^{10}$. The same mistakes are made by shipowners, depression after depression. Goulielmos (2013a), however, rejected the idea that shipowners are irrational, using Keynes General Theory. He also rejected Hampton's (1991) suggestion that groups of shipowners do not necessarily act rationally. Goulielmos (2009) addressed the question of whether history is repeated in shipping.

The paper examines the apparently irrational fact that there are excessive orders for newly-built ships when freight markets are depressed. Such activity occurred many times in the past, and also at the end of 2008 and afterwards, right up to 2013.

Investment patterns of tanker shipowners were originally described by Koopmans (1939) and Zannetos (1966). A comprehensive shipping investment theory has not yet been developed. Half of reality is captured by the dictum, "High spot rates produce high orders".

The rest of the paper is organized as follows. The next section contains the literature review. This is followed by a discussion of the relationship between orders for ships and spot rates, and then between orders and time charter rates. This discussion leads into a description of the alpha coefficient, and the relationship between current orders, deliveries and scrapping. The question is then addressed as to whether profitable time charter rates can lead to excessive orders. The results of a survey of the CEOs of Greek shipping companies are then reported, and this is followed by the conclusions.

\section{Literature Review}

Volk (1984) investigated orders during recessions. Between 1970 and 1983 orders and freight rates moved together. From 1970 to 1972 orders lagged 2.5 months behind time charters. In 1973 and 1974, orders lagged by 12 months, while in 1980 and 1981 orders led by 10 months. Economies of scale between 1960 and 1970 produced orders for larger/faster ships. Orders were placed because of replacement, high freight rates/ship revenues, loan-taking ability, and cost-saving technology. High investment activity in new buildings occurs during periods of high freight markets.

Tvedt $^{11}$ (2003) tried to bridge traditional equilibrium approach to shipping markets and maritime asset pricing. applying a stochastic optimal control model to find the effects of

\footnotetext{
${ }^{8}$ Scarsi (2007): Statistics on surplus of demand and supply provided first by Lloyd's Shipping Economist in 1976

9 Scarsi (2007)

10 Zannetos (1966); Stopford (2009)

11 Tvedt (2003) adopted the 1973 formula of Black and Scholes assuming: variation of prices in line with normal distribution; unchanged volatility over the life of an option; non-jumping prices (end-2008 depression manifested the exact opposite); taxes and commissions excluded...
} 
freight rates ${ }^{12}$. He concluded that increasing freight rates lead to higher investments. Randoy et al (2003) investigated a 3-year sample of 32 publicly traded maritime firms in Norway and Sweden compared with 96 manufacturing firms, and found that maritime firms with a CEO from the founding family have better financial performance. Syriopoulos and Tsatsaronis (2011) argued that the founding family CEO has a positive impact on the shipping firm's financial performance.

Bendall and Stend (2007) argued that a traditional discounted cash flow analysis may lead to an underestimate of the true value of investments, leaving out real options. The greater the volatility of the underlying base projects, in general, the more value strategies exist. The more strategy options there are, the more value is added. Also, the more correlated the underlying projects, the less net is value added.

Scarsi (2007) argued that "shipowners are unable to detect relevant facts or read market signals; they do not use a scientific approach or adopt a managerial culture; act by intuition; too pessimistic to invest and held back by risk; manifested excessive enthusiasm towards 'trendy' Panamax ${ }^{13}$ in 1996-2002, because of herding. Small companies are run by the founder and family head, despite that other family members disagree. Intuition prevails on discipline, priming dangerous chain-reactions". She investigated invesitment behavior of shipowners in handy-sized ships (less than 35,000 dwt), and suggested that any investment had to be in them, because of the high average fleet age, scrapping density, low order-books and growing demand. She assumed perfect competition ${ }^{14}$. She thought scrapping could be forecast exactly. There is a bias among shipowners towards investment imitation, leading to market crashes.

Chen et al (2010) investigated the relationship between daily returns and volatilities of Cape and Panamax prices (1999-2002; 2003-2008) over four major trading routes. Panamax faced more risk. The seaborne trade of iron ore and coal increased steadily, causing substantial demand (from China and India). Their tests, however, rejected normality. Chen et al (2012) argued that dry bulk shipping involves high risk, high volatility and uncertainty. They modeled $^{15}$ price behavior, and forecast spot rates on main routes for Cape, Panamax and Handymax, using the Baltic Index (1990-2010). The one-month index change contained information about demand and market sentiment for the next period. The US \$ index, and the exchange rate with the $€$, significantly influenced spot rates ${ }^{16}$. The Jarque-Bera test indicated, however, departure from normality. There were significant serial correlation in all series, and heteroscedasticity.

\footnotetext{
${ }^{12}$ Also: 'markets perfectly competitive'; demand following a 'geometric Brownian motion' and Supply working under 'constant returns to scale'...

${ }^{13}$ Scrapping for the four previous years affected Capes at 29 years of age; now at 25 . In the first quarter of 2007 $23.5 \mathrm{~m}$ dwt of orders for Capes were placed in just 3 months.

${ }^{14}$ An idea supported by McConville (1999)

${ }^{15}$ Co-integration test; application of vector error correction model; ARIMA, ARIMAX, VAR and VARX applied

${ }^{16}$ VAR and VARX performed better than ARIMA/ARIMAX.
} 
Rousos and Lee (2012) argued that ship investment decision-making is influenced by factors that are not clearly financial (so DCF, NPV, IRR are inapplicable), or they cannot be quantified. They proposed a multi-criteria system, using an analytical hierarchy process first devised by Selten (1994). They argued that shipping decision-making is heavily based on intuition, individuality and unexplained idiosyncrasies. Non-financial evidence plays an important part in the investment evaluation process. They argued that a rational asset player would rank Capes first (Goulielmos, 2013c).

Jiang and Lauridsen (2012) investigated the way shipbuilding prices of dry bulk ships are set in China. They used shipbuilding prices and principal component regression analysis (1995-2009). They found that time charter rates ${ }^{17}$ had the most significant positive impact on shipbuilding prices. The prices shipowners accept depend on market expectations. Orders fall faster than the capacity of shipyards, built at better times. This is a factor that may lead to further reductions in shipbuilding prices.

Summarizing, the pattern that high freight rates, induce high orders is supported by the papers reviewed. Leads or lags clearly exist. Theory, however, must relax the unrealistic assumptions of perfect competition and normal distribution of data. Two papers were in favor of a founding family member as CEO, a pattern which is common in Greek Shipping ${ }^{18}$. Two papers criticized the traditional methods of shipping investment evaluation. One paper singled out time charters as the main influence on shipbuilding prices.

\subsection{Do Spot Rates Influence Orders?}

Koopmans (1939) stressed that oil companies placed fewer orders during a depression. He argued that a high level of rates regularly leads to large-scale orders of new tankers. Expectations about equilibrium of supply and demand ${ }^{19}$ for ship services for a few years ahead, exert the most decisive influence on tanker buildings. This is mainly communicated through the current freight rates. High current freight rates give rise to expectations of a fair chance of profit in future tanker trade and act as an incentive to order new ships ${ }^{20}$. A depression lasts until scrapping and demand eliminate the excess capacity.

Following Koopmans' theory, let time charter TCt to be a function of the expected equilibrium of supply St and demand $\mathrm{Dt}^{\prime}: \mathrm{TCt}=\mathrm{f}(\mathrm{E}(\mathrm{St}-\mathrm{Dt}))$ [1] and $\mathrm{TCt}=\mathrm{f}(\mathrm{E}(\mathrm{LUt}+\mathrm{SSt})$ [2], where LUt is the expected laid up tonnage and SSt the expected tonnage in slow steaming. Finally, $\mathrm{Ot}=\mathrm{f}(\mathrm{TCt}, \mathrm{Ft})$ [3], where Ot are orders placed, Ft is the current freight rate (spot), TCt from [2] and $n$ counts years ahead. $n$ may be equal to the construction time. TCt exerts the decisive influence.

\footnotetext{
${ }^{17}$ Norman (1979) argued that a newly built 80,000 tons tanker in 1967-1976 earned (return on vessel's building price) almost double in the spot market, than in 1 to 3 and 3 to 7-year time charters.

18 This management style is advantageous as these CEOs are able to take very fast decisions.

19 At Koopmans' time statistics for surplus of supply over demand did not exist. Lloyd's Shipping Economist' published the relevant figures first in 1976, and eventually for 15 types and various sizes of ships.

${ }^{20}$ Owners react to rates with the same volume of building orders, irrespective of demand, which cannot be forecast.
} 


\section{Macrothink}

For a partial test of Koopmans' theory, testing its innovative feature, we ran a regression between surpluses of supply over demand for 1976-1988 and time charters for total dry bulks (Figure 1). Figures for surpluses were taken from Lloyd's Shipping Economist Supply and Demand Data in million dwt. The surplus is the sum of the tonnage absorbed by slow steaming and laid up/idle tonnage (LSE, 1986, Oct., p. 36). Demand is calculated by subtracting the surplus from supply for the three size ranges provided by Lloyds' shipping economist.

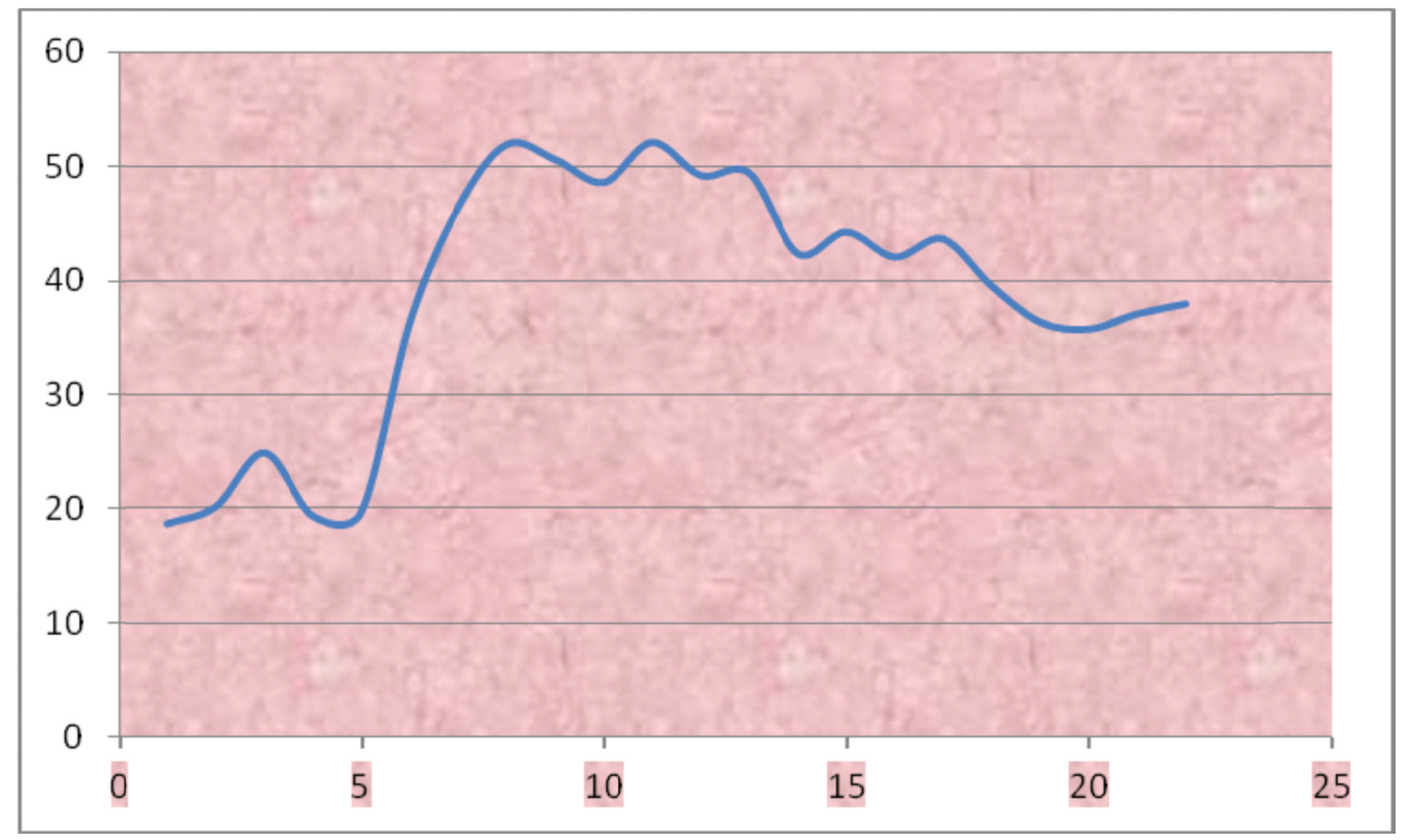

Y axis: Surplus of supply over demand. X axis number of years since after 1976 Source: Lloyd's shipping Economist

Figure 1. Surplus of Supply over Demand for Bulk Carriers, 1976-1988 (million dwt)

The correlation between surplus and one-year time charters between 1983 and 1988 for a $55,000 \mathrm{dwt}$ dry bulk carrier per day is 0.84 . This is higher than the correlation between orders and time charters found by Zannetos (0.71). In addition, Figure 1 shows the 1981-1987 depression (peaks in 1983, with 52m dwt surplus, and in 1985, with 52.2m).

Zannetos argued that orders are closely related to spot rates in the short run, and to future expectations and shipbuilding costs. Orders for new vessels and spot charters are considered indirectly complements (to form dynamic expectations). Zannetos, in order to follow Hicks (1946), used spot rates. Hicks (p. 205), in contrast to Keynes, argued that a change in current price makes people feel that they can recognize a trend, which they try to extrapolate (formation of elastic expectations). 


\section{MInstitute ${ }^{\text {Macrothink }}$}

\subsubsection{Scrapping and Orders}

Scrapping (old/obsolete vessels) affects orders. Scrapping is determined by age, technology and expected charter rates $^{21}$. Technology affects replacements ${ }^{22}$. Low spot rates will accelerate scrapping during depressed periods ${ }^{23}$. Zannetos (1966) argued that a certain number of orders will be placed anyway, due to the age of existing vessels, prevailing charter rates and technology.

\subsubsection{Zannetos' Paradox}

Zannetos (1966) was surprised to see a change of ship-owners' expectations in an abrupt and regular manner, from elastic to inelastic, and back to elastic. He, studied orders and correlated them with the index of monthly spot rates (1949-1958). This pattern, he said, could happen only if operatives had no memory. It was then that the term "zero memory of shipowners" appeared. As shown in Figure 2, by connecting the scatters of Zannetos between monthly rates and orders, certain loops appear moving on the periphery of a crude figure eight.

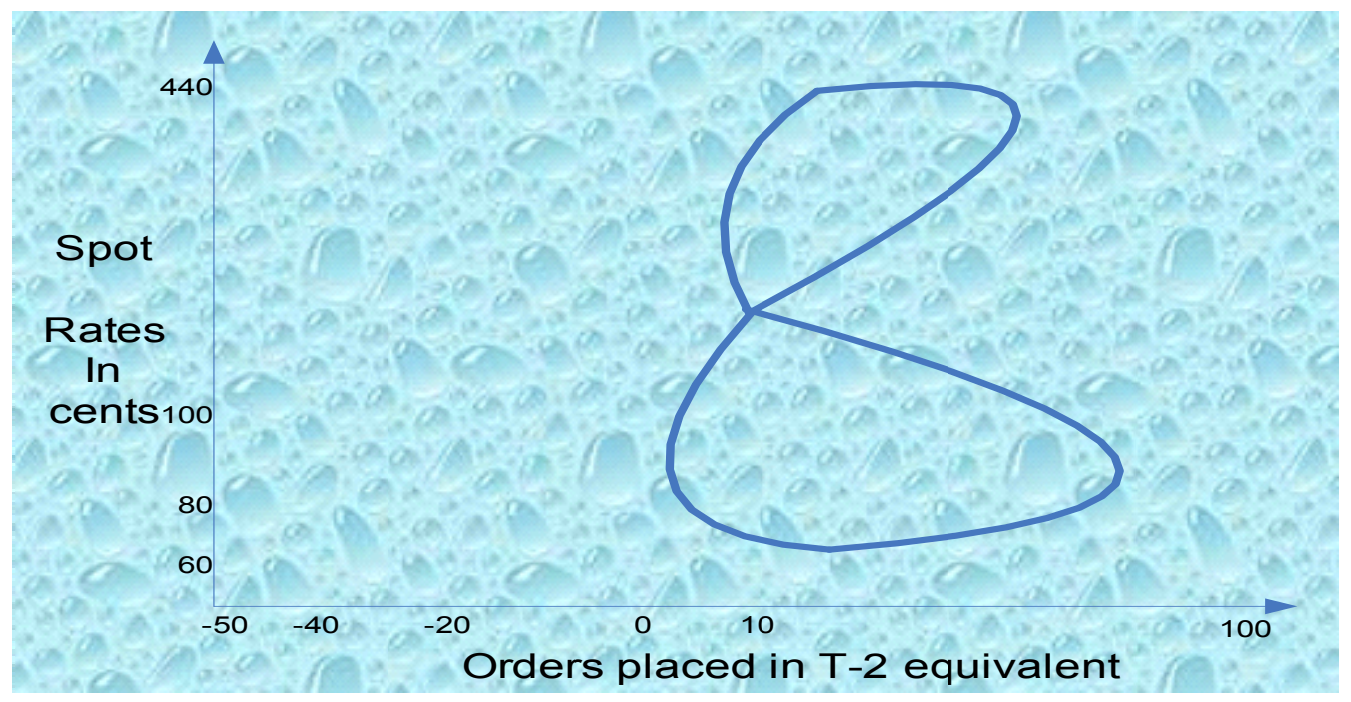

Source: Zannetos (1966)

Figure 2. Orders placed plotted against index of spot rates (monthly), 1949-1953

One turning point in expectations appears at 280 cents per 1000 ton miles (middle). Another occurs at 130 to 140 cents, considered remunerative for most of the small tankers of T2 size (16,500 dwt) at Zannetos' time, including the Korean War (1951-1952). A third occurs at 420 cents.

\footnotetext{
${ }^{21}$ Given that AVC increases with age, total cost/dwt of a new-similar ship is less than the average variable cost (AVC) of old one.

${ }^{22}$ Total cost of a new ship is less than AVC of the replaced one.

${ }^{23}$ The current rate is less than AVC; expected revenue of the remaining dwt is less than the AVC of the vessel's physical life.
} 


\section{Macrothink}

\subsection{The Alpha Coefficient, 1999-2009}

The Alpha ${ }^{24}$ coefficient for BPI is shown in Figure 3. Shipping depressions can be defined as bubbles (Stokes, 1997), characterized by a low alpha less than 2 and even less than 1.70 - the Mandelbrot benchmark. According to conventional economics, investment bubbles are irrational deviations from the norm, caused by a rapacious speculator, mass greed, and so on ${ }^{25}$. However, an alternative interpretation suggests that investment bubbles are entirely rational and flow from the entwined effects of long-term dependence ${ }^{26}$ (the Joseph Effect) and discontinuity (the Noah Effect) (Goulielmos, 2013b). Ship-owners, by and large, are rational investors.

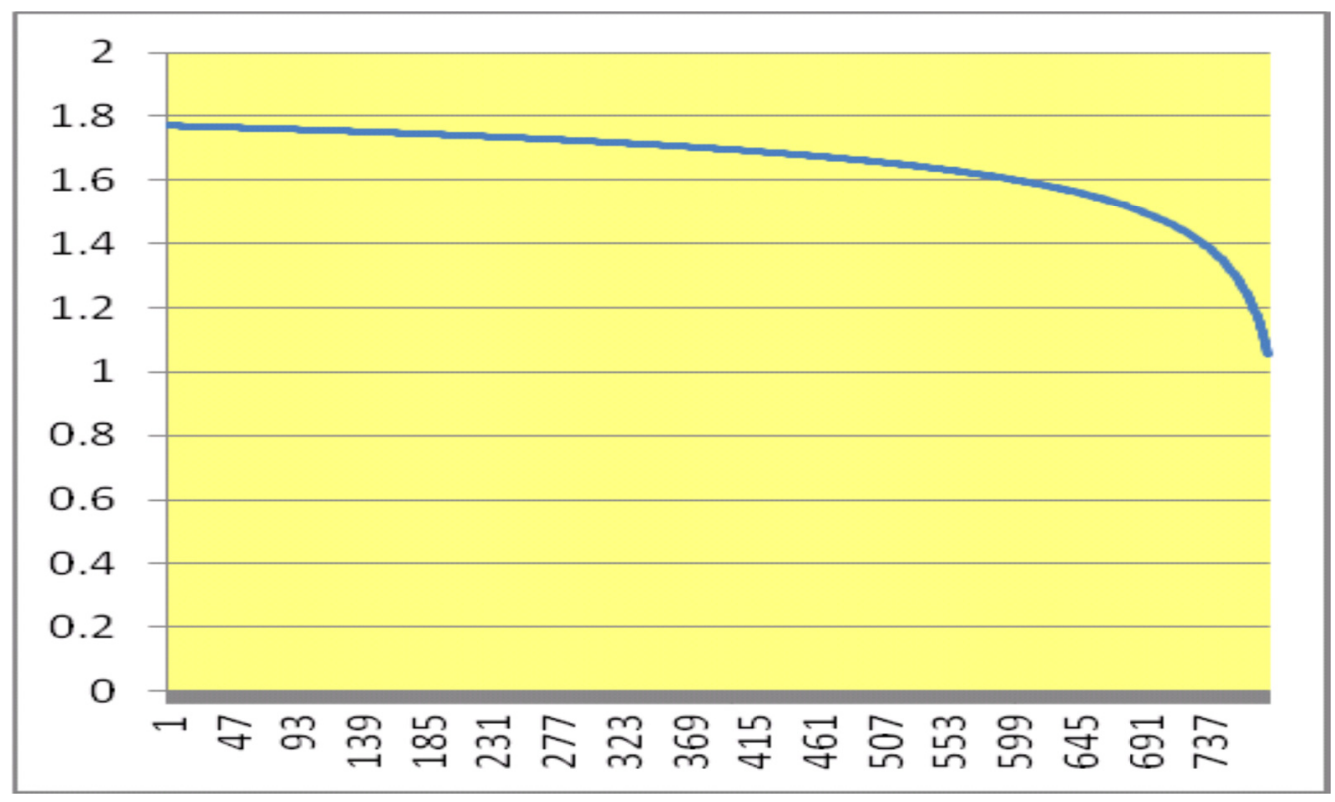

Source: Data Clarksons; NLTSA (2000); alpha=1/H

Figure 3. Alpha for Freight Markets - BPI (1999-2009) by day

As shown, the alpha coefficient of the 3,439 (10 years) daily BPI freight rates, was close to 1 (1.09). This means that freight markets cannot be described by a normal distribution ${ }^{27}$ (Goulielmos and Psifia, 2011), as alpha is much less than 2. Also BPI cannot be described by a Levy-stable distribution ${ }^{28}$ in between with $\alpha=1.50$. BPI tails are really fatter and freight rate

\footnotetext{
24 This is the measure of what kind of peak the probability density function has (indicating risk or fat tails). $1 / \mathrm{H}=$ alpha (Peters, 1994).

25 Mandelbrot and Hudson (2006) in another context

26 A measure of bias in fractional Brownian motion, indicating the persistent or trend-reinforcing series and the anti-persistent or mean-reverting systems (Peters, 1994).

27 This is a continuous probability distribution where its mean does not exist and its variance is infinite; only the fractional absolute moments exist.

28 A Levy-stable distribution in between has alpha=1.50; it is slightly more tall and slightly more narrow than normal distribution and with tails slightly fatter, but less extreme than in the Cauchy distribution.
} 


\section{Macrothink}

markets are riskier. This increase in risk is due to the depression at the end of 2008. Such markets are prone to wild swings ${ }^{29}$. In addition, Weatherall (2013) argued that distributions with alpha between 1 and 2 do not have a well-defined average variability (volatility/variance).

Alpha is calculated by a statistical, non-parametric, method, rescaled range analysis, developed by Mandelbrot and Hurst (2006), enabling ${ }^{30}$ researchers to separate Joseph and Noah Effects (names given by Mandelbrot). Alpha indicates the size of events, which act on freight markets and bring catastrophes, like depressions. Alpha indicates shipping depressions if it has values less than 2 and certainly less than 1.70 .

\subsection{Orders and Rates: 1999-2009}

Figure 4 shows monthly orders and time charter rates on four routes for the years 1999 to 2009 for Capes. Capes were chosen because their orders were excessive before and after the depression at the end of 2008.

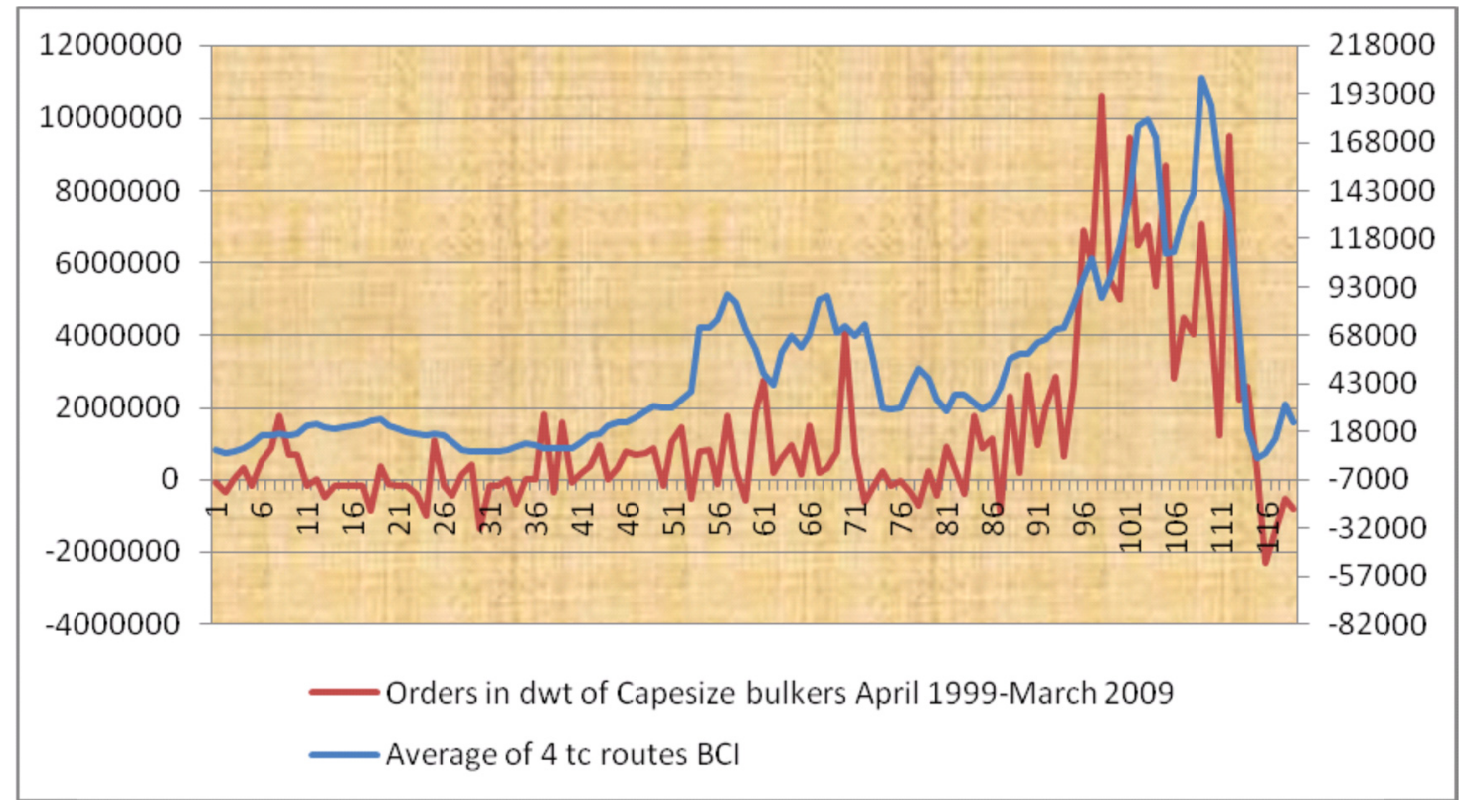

$\mathrm{Y}$ axis left hand side shows orders in dwt, right hand side shows time charter rates. $\mathrm{X}$ axis shows months Source: Clarkson's data

Figure 4. Orders for Capes (dwt per month) and Time Charters in dollars, 1999-2009

The close relationship between orders and time charter rates for Capes is clear in Figure 4. Zannetos' paradox is also shown, as orders are placed at low time charter rates (e.g. August to September 2001). Orders placed between 1999 and 2002 were less than $2 \mathrm{~m}$ dwt per month, a low level, with frequent cancellations. This period shows a trial and error behavior. It was

${ }^{29}$ Mandelbrot and Hudson (2006) in another context

${ }^{30}$ Nonlinear Time Series Analysis (2000). Also using MATLAB (2009). 


\section{Macrothink}

between 2003 and 2008 when orders became high, following the exceptionally high freight rates. Orders exceeding $2 \mathrm{~m}$ dwt per month were placed in 2003-2005 and in 2007-2008.

On closer analysis. orders in dwt for Capes, show a lag, which varied from 6 months in 2004 to 11 months in 2008. The higher the time charter rate, the higher the monthly orders. The correlation coeficient is 0.74 . Zannetos (1966) found a value of 0.71 in his spot rate regression, with a 3 month lag for 1949 to 1958 for tankers. So, time charters used here give a higher correlation than the spot rates.

Orders per month for Capes between May 1999 and March 2009 peaked in June 2007 at a level of more than 4 million dwt per month. The order-book also had cancellations - shown by the negative figures - mainly between 1999 and 2002. Cancellations reached a peak of more than $2 \mathrm{~m}$ dwt in December 2008. The average time charter at which cancellations took place varied from $\$ 7,047$ to $\$ 24,397^{31}$. The above investment activity is quite rational.

\subsection{Orders, Deliveries and Scrapping, 2006-2013}

Orders for dry cargo ships between 2006 and 2013 varied from about $72 \%$ to about $7 \%$ of the existing fleet as shown in Figure 5, reaching 1,475m dwt (or $290 \%$ of the existing fleet). A depression obviously did not stop orders.

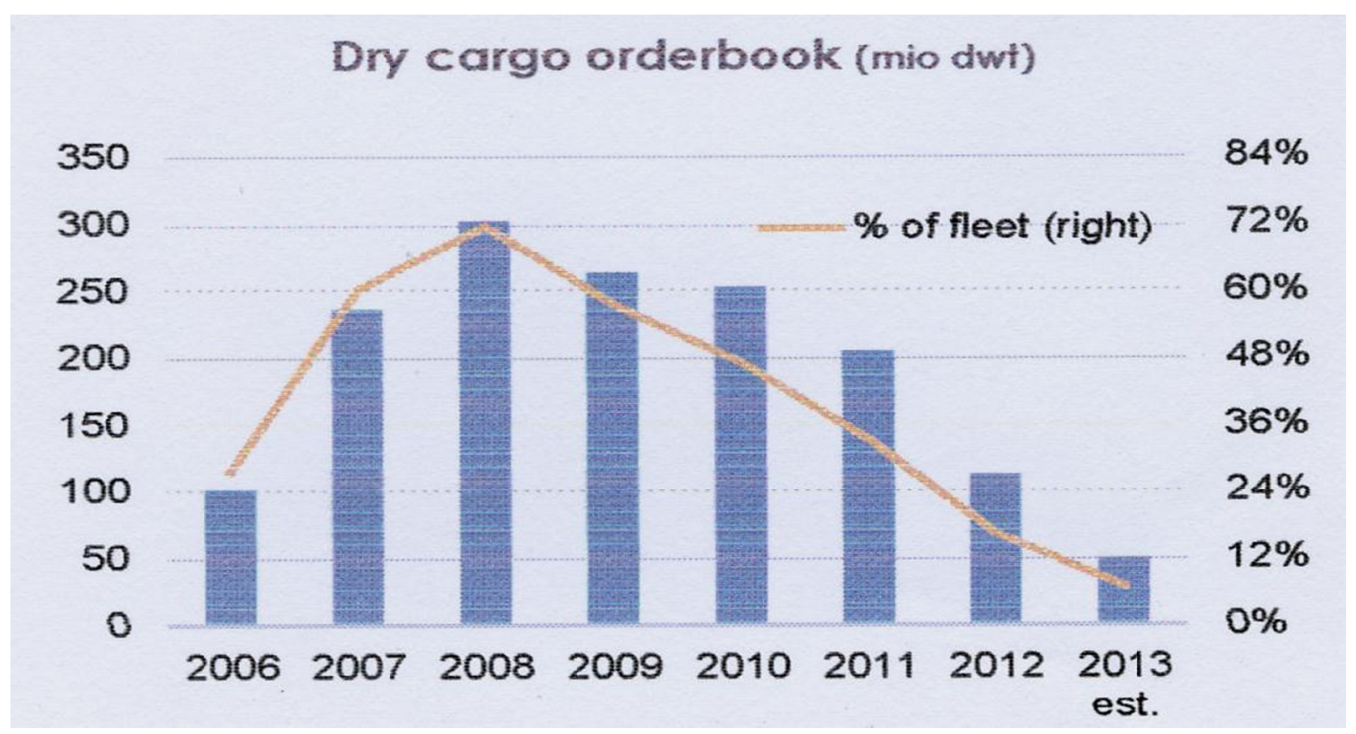

Source: J Grieg \& Co (2012) Annual Report, used with permission

Figure 5. Dry cargo order-book, in million dwt and as a percentage of the existing fleet, 2006-2013

Orders for dry cargo vessels fell by 50m dwt after the peak a the end of 2008 (not shown). Orders were lower between 2010 and 2013, but they did not stop as one would expect after the crisis at the end of 2008. In 2013, 50m dwt, or 7\% of the existing fleet, was on order. This

${ }^{31}$ For a Greek shipowner, Capes need $\$ 30,000$ per day to operate. 
persistence of orders is a new element of this depression.

As shown in Figure 6, the number of ships ordered in August, 2013, was 252 or 49m dwt. The all period peak was recorded in October 2008 with 884 Capes, 164m dwt. Ordering momentum $^{32}$ started in September 2006 with 194 ships. Moreover, orders show cyclicality with a six-year cycle starting in January 2007 and ending in January 2013.

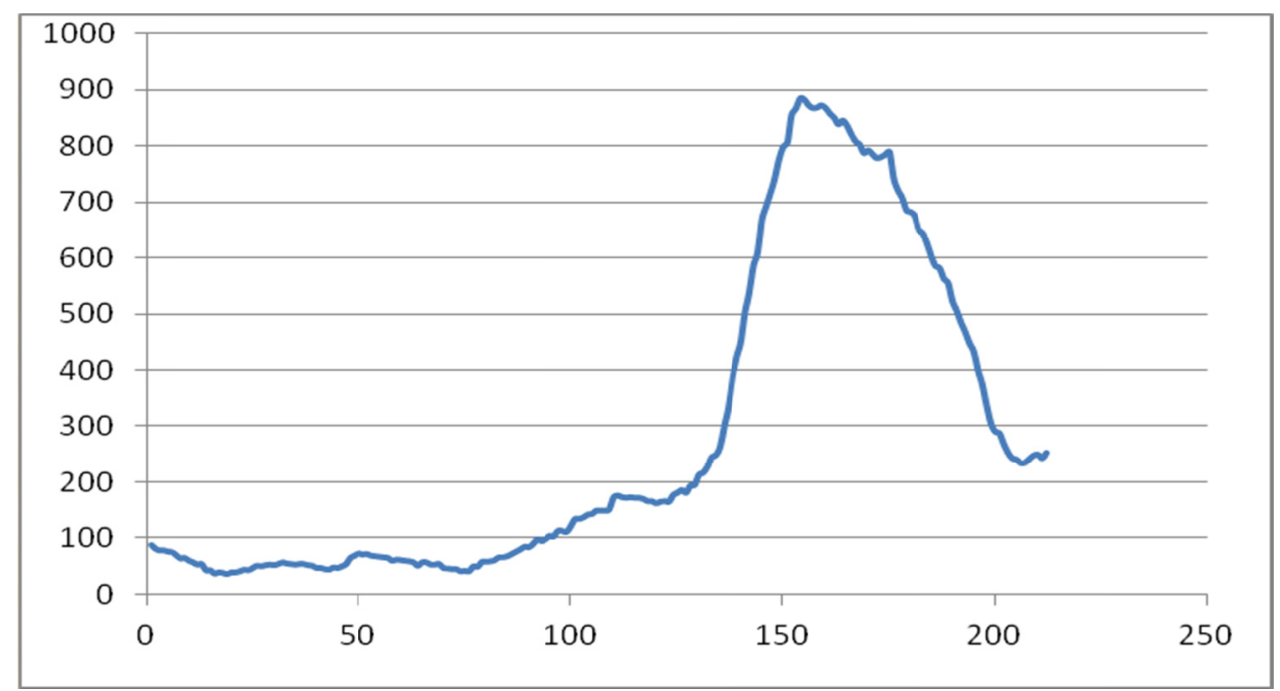

$\mathrm{Y}$ axis $=$ number of ships. $\mathrm{X}$ axis: Months

Source: Clarkson's data

Figure 6. Cape Orderbook, January 1996 to august 08/2013 (ships)

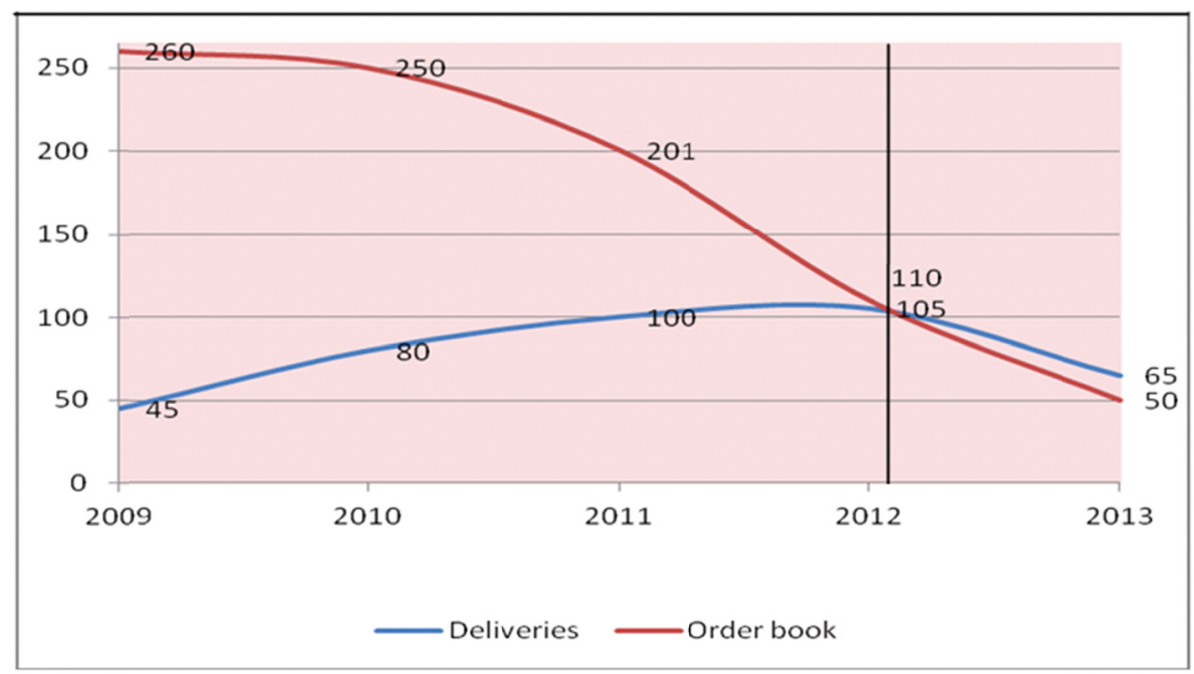

Source: Data from J. Grieg \& Co (2012)

Figure 7. Deliveries and orders of dry cargo ships, million dwt, 2009-2013

\footnotetext{
32 The Capes orderbook has a long term memory when tested by the value of $U$ variable $\left(U=R / S / V_{n}\right.$, where $R / S$ is the range divided by standard deviation and n number of observations). $\mathrm{U}$ is found to be equal to 2.16 and to be less than 2.098 for $0.995 \%$ probability (Lo, 1991), using NLTSA.
} 


\section{Macrothink}

As shown in Figure 7, the peak for deliveries of dry bulk carriers occurred four years after the peak in orders (2009 and 2013 respectively). The delivery period, however, is much longer.

In a depression shipowners try to postpone deliveries (or cancel orders ${ }^{33}$ ). During a boom, the construction period is about one year on average or even less. $395 \mathrm{~m}$ dwt in dry cargo ships were delivered to owners between 2009 and 2013. Deliveries varied from $7.5 \%$ of the existing fleet in 2009 to $16 \%$ in 2012 . This indicates that shipowners always hope that a depression will be over quickly. The hope for a recovery among shipowners, unlike bankers, is stronger than the threat of bankruptcy.

Scrapping is believed to be an effective mechanism to restore the market to equilibrium. Between 2009 and 2013 scrapping reached $103 \mathrm{~m}$ dwt, varying from $2.5 \%$ of the existing fleet to 5\%. As shown in Figure 8, scrapping is not an effective mechanism for removing surplus tonnage. Usually, it removes less than a third of the delivered tonnage. The period 1981 to 1987 was exceptional, when the level of scrapping was almost double that of deliveries.

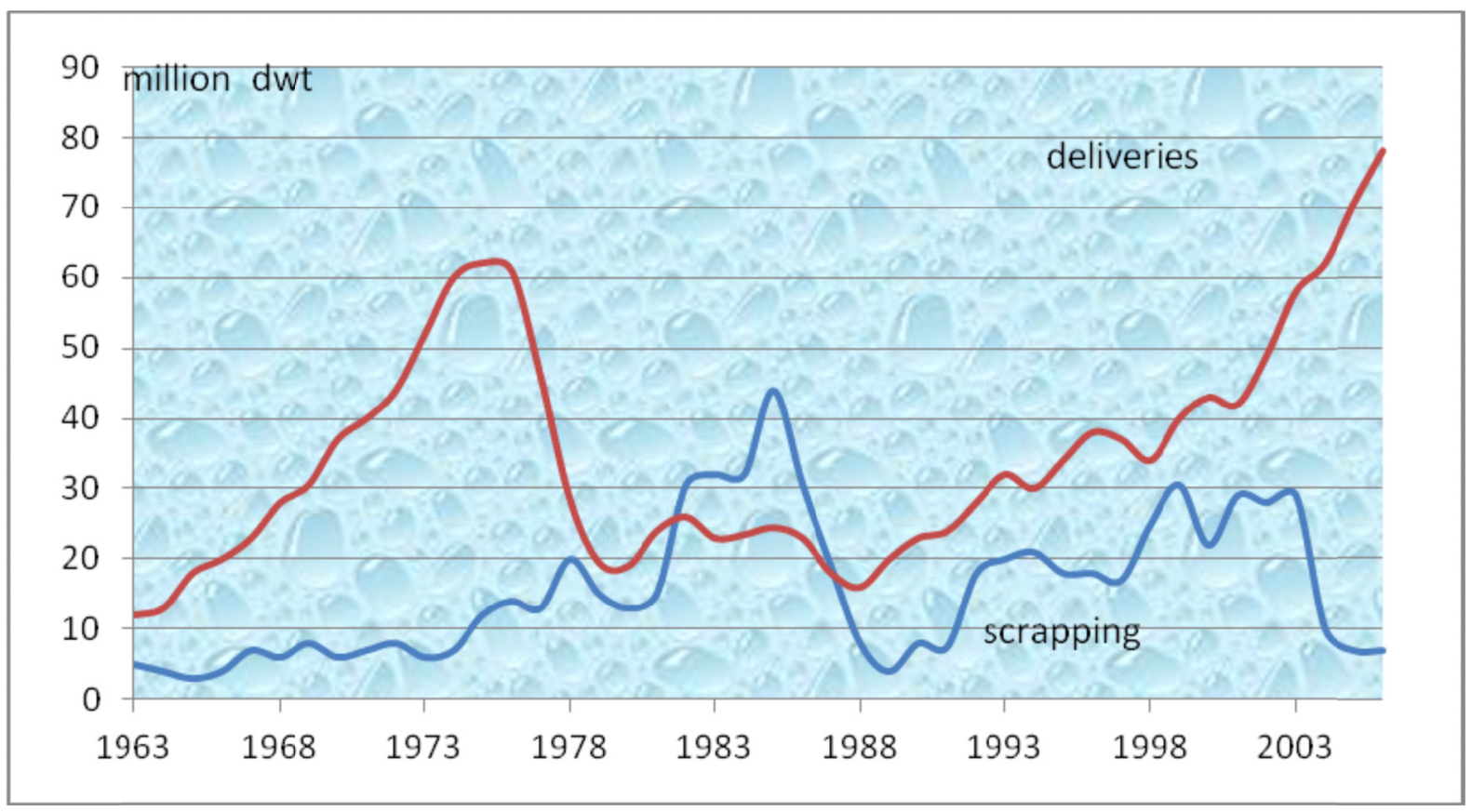

Source: UNCTAD (2007)

Figure 8. Deliveries and scrapping, 1963-2006

As shown in Figure 8, scrapping exceeded deliveries only in the period 1982 to 1986, and this was as much due to a fall in deliveries as to a rise in scrapping.

\subsection{Excessive Bulk Carrier Orders, 2000-2011}

Orders for bulk carriers rose above 50m dwt after 2003, as shown in Figure 9, and reached a peak in 2008.

\footnotetext{
${ }^{33}$ Greeks cancelled 9.4m dwt (37\%) of tankers (August, 1974-December, 1975) on total orders of 25.4m dwt.
} 


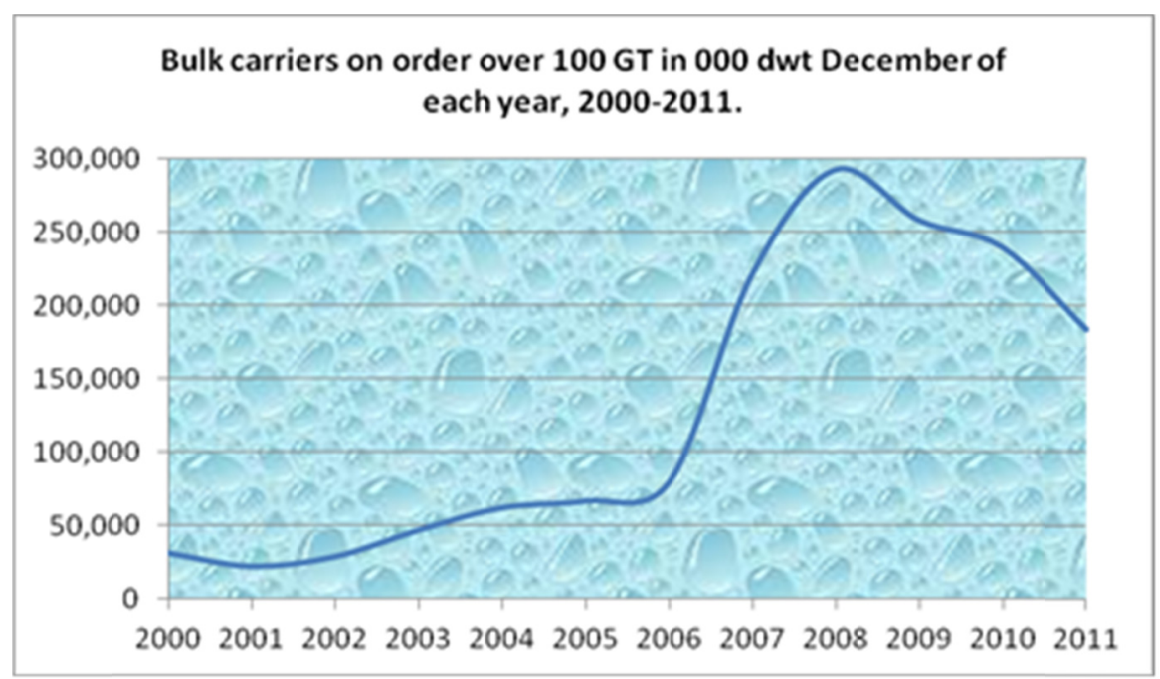

Source: Data from UNCTAD, Review of Maritime Transport (2012)

Figure 9. Orders of bulk carriers, 2000-2011 (000s of dwt)

There is also an exceptional activity in orders between 2009 and 2013. Orders over the period from 2009 to 2011 varied from $180 \mathrm{~m}$ dwt to $270 \mathrm{~m}$ dwt per year.

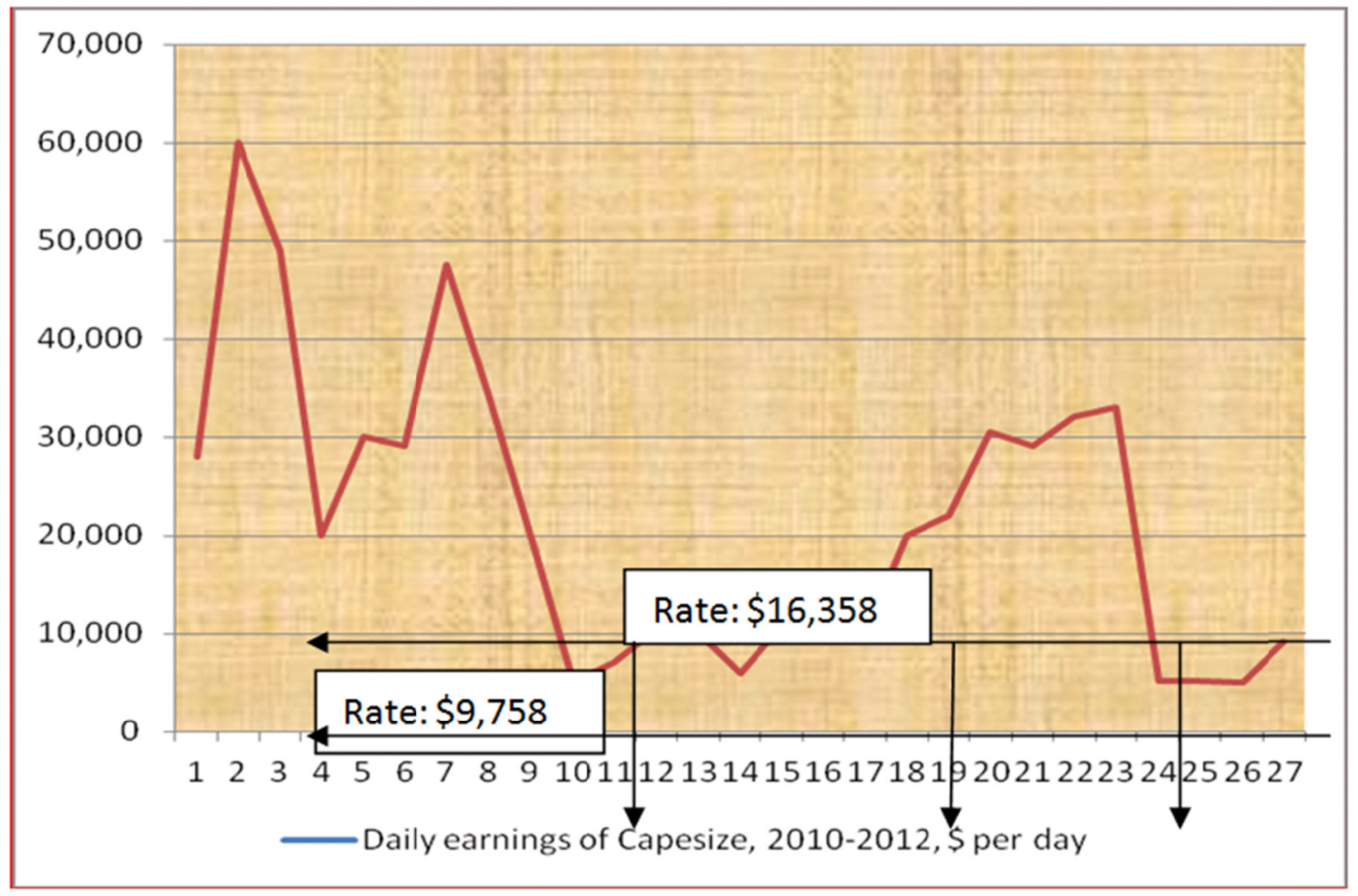

Source: Data from UNCTAD (2012); average over 4 routes T/C Figure 10. Daily earnings of Capes, 2010-2012 


\section{Macrothink}

As shown in Figure 10, daily earnings from Capes between April 2010 and January 2011, and from October 2011 to March 2012, were over $\$ 16,000$. \$16,000 is chosen as the cut-off level for orders, as ships break even at that level. However, this cut-off rate can be reduced to $\$ 9,800$ per day due to the lower level of capital needed (prices) because of the depression. Orders placed at low charter rates over 4 months in 2011 and 4 months in 2012 support Zannetos' paradox.

A depression means that less capital is needed due to lower new building prices as shown in Figure 11. This may be combined with lower operating costs due to fuel saving technology (and IMO regulations for lower $\mathrm{CO}_{2}$ emissions) and the efforts of companies to cut operating costs further to cope with the depression. Shipping companies feel the depression when the time charter rate falls below $\$ 9,758$ for Capes. Actual rates were higher than this from October 2012 to December 2012 and from July 2013 to October 2013, reasonably stimulating new orders.

\subsection{Why Greek CEOs Ordered Ships in 2013?}

This section reports the views of CEOs of Greek shipping companies, gathered through interviews in May 2013. Greek owners, under whatever flag they registered, invested $\$ 13 \mathrm{~b}$ in 2013 - a depression year - to purchase more than 300 new buildings to add to the 3,669 vessels they already had, making a total of $261.63 \mathrm{~m}$ dwt or $16.16 \%$ of the global fleet and $47 \%$ of the EU fleet.

EastMed, with more than $3.5 \mathrm{~m} \mathrm{dwt}$, ordered new ships because of the lower prices compared with 2008, but did not anticipate a substantial improvement of profitability over next two years or a rapid recovery of freight markets, because of previous over-ordering and the slow recovery of the world economy. Greeks had good liquidity, from the boom of 2003 to 2008, and used their experience of the preceding economic depression (1981-1987) not to proceed with irrational orders ${ }^{34}$. Low prices contribute to company's fleet renewall with ships of new technology.

In the cargo depression of 1981 to 1987 , Greeks sold smaller and older units and obtained younger and larger ships at lower prices. This taught them to do the same in 2013. However, the 2008 depression will last longer (Goulielmos, 2013 a, b). Abundant crisis reserves will save prudent shipping companies from depression, not only their past experience. It is also important whether a depression follows a boom, like that of 2003 to 2008.

\footnotetext{
${ }^{34}$ Greeks ordered 544 vessels, \$7.1b in 2010; \$9.2b in 2011 and \$5b in 2012, including high priced ships (gas carriers; large containerships). Capital Product Partners bought a 5,023 TEU containership for $\$ 130 \mathrm{~m}$ chartered to Hyundai for 12 years at $\$ 29,350$ p.d. In March 2013 Greeks ordered 282 ships of $18.4 \mathrm{~m}$ dwt compared with 25.5 in 2012. \$7.4b was devoted to building LNG in February 2014.
} 


\section{Macrothink}

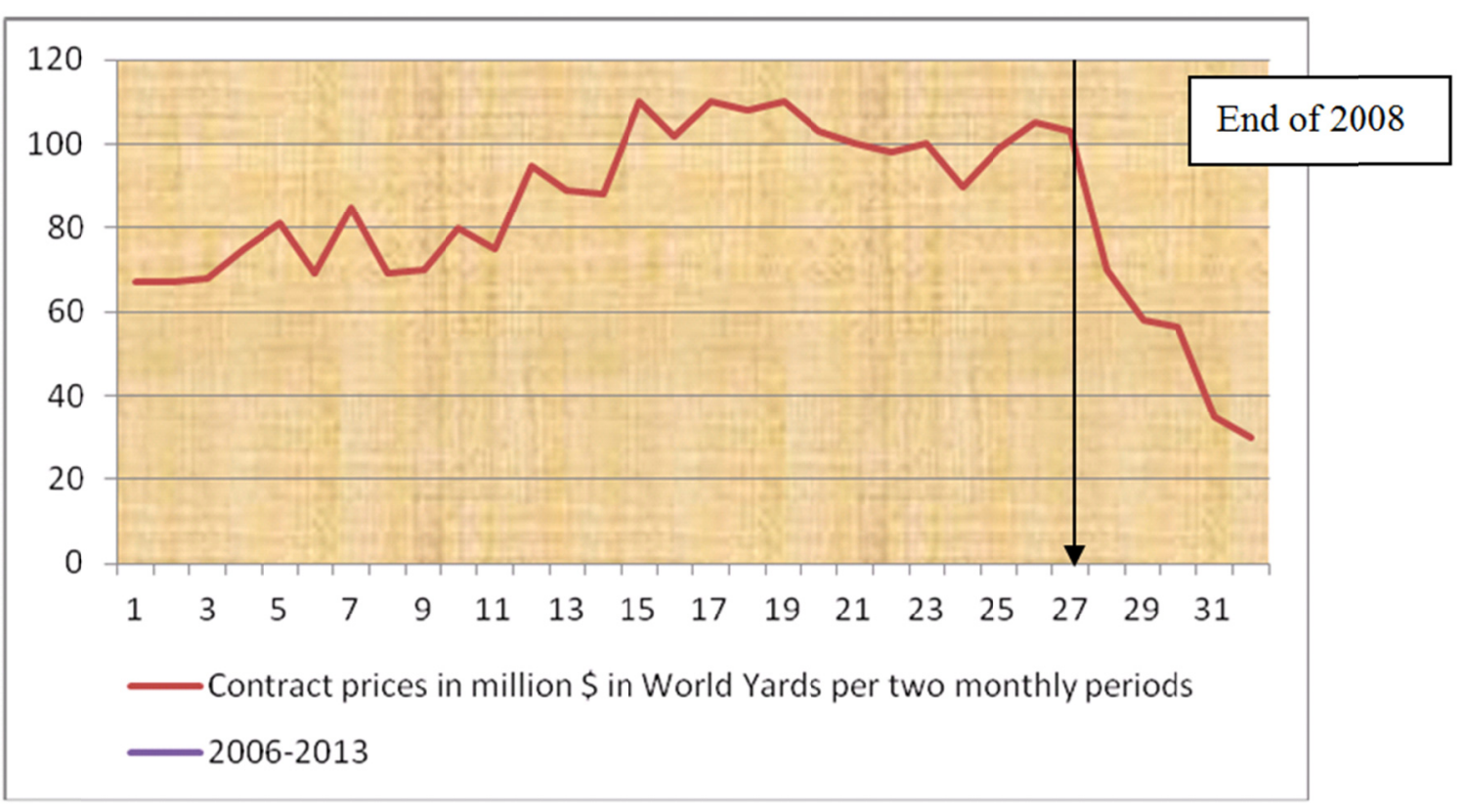

Source: Clarkson's data

Figure 11. Shipbuilding prices for Capes, November 2006 to 2013 (\$ millions)

As shown, a Capes vessel costing $\$ 110$ million in 2008, cost $\$ 58 \mathrm{~m}$ in 2009 and $\$ 30 \mathrm{~m}$ in 2013 $\left(1^{\text {st }}\right.$ quarter). The difference of $80 \mathrm{~m}$ in price is important, as it makes a vessel $35 \%$ more competitive. Moreover, Capes were less risky than Panamax - though larger - between 2001 and 2009, contrary to previous research (Goulielmos, 2013c; Chen et al., 2010).

Given that a Cape earned about $\$ 200,000$ per day in 2008, a Panamax $\$ 100,000$ and a Handymax $\$ 70,000$, and their respective earning capacities in 2013 were Capes $\$ 4,448$ day, Panamax \$8,982, Supramax $\$ 9,457$ and Handysize $\$ 7,921$, the profitabilities can be calculated as roughly $0 \%$ for Capes, $30 \%$ for Handysizes, $32 \%$ for Handymaxes and $22 \%$ for Panamaxes (UNCTAD, 2012). This implies that the expected life-time performance of a new vessel is important when ordering ships. Moreover, a ship can recoup her full cost (plus profit) in time shorter than her life time, thanks to the exceptional freight rates and high resale/scrap values that might prevail (for example over the period 2003 to 2008).

Navios Maritime ordered three tankers and took out two options due to the low prices. Navios Holdings bought four new ships from Japanese yards due to the low Yen/\$ parity. Sea Pioneer ordered new-buildings due to historically low prices. The new more efficient ships in terms of fuel consumption and emissions are promoted also by shipyards. ECO ships offer substantially reduced SOX and NOX, from 3 or 4 tons a day to 20, depending on size.

Moundreas' CEO stated that fuel efficiency and safety preoccupied shipowners. Ever increasing fuel costs and public awareness of pollution and environmental emissions make ECO ships with a limited speed of 12 to 14 knots more attractive. Time-charterers encourage owners to build ECO ships. These ships save, on average, $\$ 3,250$ per day compared with older, non-ECO ships. 
Iolcos Maritime ordered 18 Panamax after $2003^{35}$. This was due to lower prices, and lucrative financing terms offered by shipyards, in addition to considerations about ECO ships. Despite the recent crisis, the order-book in 2013 is healthy. StealthGas' CEO argued that Greeks made money during the previous crisis and stressed that the present crisis is in housing, banking and the global economy. 1,000 Capes ordered in 2006 to 2010, are now earning $\$ 5,000$ per day, while they really need $\$ 30,000$. He opined that prices are close to the bottom.

The CEO of Arion shipping said that opinions expressed about the future course of markets, and world trade, affected the psychology of shipowners in 2003 to 2008 so as to rush for orders. Eletson argued that shipping knows how to live with depressions, and that crisis was inevitable due to over-ordering. The CEO of Karlog Shipping argued that only fund equities now invest in low-priced ships. Marmaras ordered three Capes and took out three options believing in an improved market after 2014. Ocean Star chartered three newly built Supramax to Cargill at $\$ 10,000$ per day for 12 to 15 months, gaining also $\$ 1,500$ from fuel cost-saving.

In 2012 Seanergy lost roughly $\$ 27 \mathrm{~m}$ compared with $\$ 4 \mathrm{~m}$ in 2011 . A time charter-equivalent at $\$ 7 /$ day per vessel prevailed in 2012 , the lowest since 1997 . Net revenue of roughly $\$ 56 \mathrm{~m}$ in 2012 fell $47 \%$ in one year. Thenamaris secured a $\$ 400 \mathrm{~m}$ loan for three LNG new-buildings from Korea Eximbank (KEXIM), syndicated with three other banks. In February 2013, Greeks had a $35 \%$ share in the world $\mathrm{LNGs}^{36}$ and ordered 37 ships priced round $\$ 200 \mathrm{~m}$ each.

\section{Conclusions}

Shipping research did not support the idea that investment is based on a ship's expected discounted net present value of revenue over its lifetime, as Keynes proposed. The catastrophe in freight markets came unexpectedly. What shipowners really do not know is when a depression is going to appear, and more important, how long it is going to last. Here is where research must help shipping, by forecasting depressions. Shipowners committed errors in the past, assuming depressions would be shorter than they actually were. Shipowners are basically optimists. Greeks believe that the sea gets sick, but never dies.

Banks with a shipping division in Hong Kong reduced lending to shipping after the recent financial crisis (Gong et al., 2013). This is a classical reaction from inexperienced banks with shipping, acting in a short-sighted way, and ignoring that depressions create opportunities. Also, shipping is cyclical. Investment projects should be considered over a full cycle, instead from peak to low, as banks usually do.

Maritime research did not pay enough attention to the investment criterion proposed by Koopmans, namely the disequilibrium of supply and demand. We show above that, statistically, he was right, as his proposal produces a higher correlation with orders than with spot rates. Zannetos favored spot freight rates, because he wanted to confirm Hicks' theory of elastic expectations. Norman also favors of spot rates. Koopmans compromised with the use of spot freight rates as a proxy for equilibrium of supply/demand, expectations of profit and

\footnotetext{
$35 \$ 700 \mathrm{~m}$ invested in 6 years.

${ }^{36}$ World fleet $(2014)=399$ ships. On order $=110(\sim 28 \%)$. This market has prospects as being friendly to environment and schists (mainly in USA) which emerged as source.
} 
incentives to order. However, time charter rates have played an increasing role compared with spot rates. Their greater influence was also noted in Chinese shipbuilding prices.

The market produced exceptionally high freight rates over the period 2003 to 2008, which resulted to excessive orders for dry cargo ships in general, especially Capes, serving mainly demand in China and India. Shipowners, between 1999 and 2002 adopted a trial and error approach to ordering ships. The sudden death of the freight market - the emergence of the Joker at the end of 2008 (the Noah effect) - stopped shipowners for a while, until freight rates rose again to $\$ 80,000$ per day (Capes). This again caused excessive orders. Employment of Capes continued almost uninterrupted to October, 2013, with average of over $\$ 15,000$ per day.

Orders placed during a depression are also influenced by attractive terms offered by shipyards and banks ${ }^{37}$, motivation offered by governments ${ }^{38}$. All these motivate shipowners to order ships. A fine example is the policy of Japanese shipyards in $1975^{39}$. In October 2013 China wished to maintain its $46 \%$ share of all world orders in dwt (Korea 35\%; Japan 12\%).

Orders are also placed because of new technology (e.g. ECO ships). New technology imposed by IMO to reduce gas emissions, also created orders. Ships that prosper are also ordered, such as gas carriers, large containerships and offshore units. Ships are ordered primarily because of their low price. All ships cut daily costs in a depression. Lower shipbuilding prices in a crisis induce owners to order, as capital cost accounts for half the total cost. Any attempt to explain orders by examining only the influence of spot rates is bound to be partial and misleading.

Certain Greek shipowners believe that the 1981 to 1987 depression is being repeated. But, for the size of events - expressed by the alpha coefficient tending to 1 - things are much more risky. Shipping companies will be tested for their resistance over a long depression after 2008.

Scrapping - the ultimate hope for rescuing shipping - and a very sad proof of a great waste of resources in wrongly-timed investments - is influenced by freight markets. In eight months in 2013, 15m dwt of dry bulk carriers were scrapped. But scrapping handles a maximum of one third of the existing surplus. Sometimes scrapping takes as long as 13 years to restore equilibrium, due to the volume of ships to be scrapped. Cost control is one of the three basic pillars of bulk shipping companies - depression or not - as they cannot control prices. The other two are forecasting and the creation of adequate depression reserves.

Greek shipping CEOs remember the 1981 to 1987 depression. They are unlikely to remember

\footnotetext{
37 DNB provided in 2012 \$26b of shipping loans followed by Commerzbank (\$25b) and Bank of China (\$24b), out of 39 banks. Total $\$ 75 b$.

38 Athena $\mathrm{Wu}$, Chinese shipping finance, $13^{\text {th }}$ Mare Forum, Amsterdam, Oct. $22^{\text {nd }}, 2013$ (downloaded in Nov. 2013).

39 The credit terms offered by Japan in 1980, less favorable than those in 1975, were: 10 years tenor, $65 \%-90 \%$ credit, 2\%-4\% interest; 3 years moratorium (Fairplay, 21/02/1980). China offers now mainly: 12 years from delivery; $80 \%$ max. of contract price . Interest rate: floating or fixed.
} 
the 1929 to 1937 one. Four factors induce Greek shipowners to order during present depression: lower new building prices, high prior liquidity, and new technology, including a requirement for new technology imposed by regulators (IMO), and a favorable shipyard, banking and governmental environment. A depression creates opportunities for companies with liquidity. The crucial question now is whether the liquidity created over the period 2003 to 2008 supports the current investment programs, as markets in 2014 and after surely will not, because of the low rates which may not even reach the breakeven point.

\section{References}

Bendall, H. B., \& Stent, A. F. (2007). Maritime investment strategies with a portfolio of real options. Maritime Policy and Management, 34, 441-452. http://dx.doi.org/10.1080/03088830701585183

Chen, S., Meersman, H., \& van de Voorde, E. (2010). Dynamic interrelationships in returns and volatilities between Capesize and Panamax markets. Maritime Economics \& Logistics, 12, 65-90. http://dx.doi.org/10.1057/mel.2009.19

Chen, S., Meersman, H., \& van de Voorde, E. (2012). Forecasting spot rates at main routes in the dry bulk market. Maritime Economics \& Logistics, 14, 498-537. http://dx.doi.org/10.1057/mel.2012.18

Eurofin. (2013). Koenig J F, Today's Ship Finance Environment, 13 ${ }^{\text {th }}$ Mare Forum Shipfinance 2013 conference (downloaded Nov. 2013).

Gong, S. X., Ye, H. Q., \& Zeng, Y. Y. (2013). Impacts of the recent financial crisis on ship financing in Hong Kong: a research note. Maritime Policy and Management, 40, 1-9. http://dx.doi.org/10.1080/03088839.2012.745202

Goulielmos, A. M., \& Psifia, M. E. (2011). Forecasting short-term freight rate cycles: do we have a more appropriate method than a normal distribution? Maritime Policy and Management, 38, 645-672. http://dx.doi.org/10.1080/03088839.2011.556673

Goulielmos, A. M. (2009). Is History repeated? Cycles \& Recessions in Shipping Markets, $1929 \&$ 2008. Int. J. of Shipping \& Transport Logistics, 1, 324-360. http://dx.doi.org/10.1504/IJSTL.2009.027679

Goulielmos, A. M. (2013a). Keynes economics of depression: The shipping industry as a case-study. Journal of Research in Economics and International Finance, 2, 13-28.

Goulielmos, A. M. (2013b). The end-2008 Shipping Depression: is this the last of its kind? Paper submitted for special issue of Int. Journal 'Spoudai'.

Goulielmos, A. M. (2013c). An Econometric Analysis of the impact of vessel size on weekly time charters: a study in volatility (Panamax and Cape). International Journal of Transport Economics, $X L, 31-48$.

Hampton, M. J. (1991). Long and Short Shipping Cycles (3rd ed.). Cambridge Academy of Transport, Cambridge, UK. 
Hicks, J. R. (1946). Value and Capital: An inquiry into some fundamental principles of economic theory (2nd ed.). Oxford, UK.

Jiang, L., \& Lauridsen, J. (2012). Price formation of dry bulk carriers in the Chinese shipbuilding industry. Maritime Policy and Management, 39, 339-351. http://dx.doi.org/10.1080/03088839.2012.671544

Koopmans, T. C. (1939). Tanker freight rates and tankship building. Garlem, Netherlands.

Lo, A. (1991). Long term memory in stock market prices. Econometrica, 59, 1279-1313. http://dx.doi.org/10.2307/2938368

Maloni, M., Paul, J. A., \& Gligor, D. M. (2013). Slow steaming impacts on ocean carriers and shippers. Maritime Economics \& Logistics, $15, \quad$ 151-171. http://dx.doi.org/10.1057/mel.2013.2

Mandelbrot, B. B., \& Hudson, R. (2004). The (Mis) behavior of markets. Basic Books, NY.

McConville, J. (1999). Economics of Maritime Transport: Theory and Practice (1st ed.). Institute of Chartered Shipbrokers, London.

Norman, V. (1979). Risk on the spot market overestimated. Norwegian Shipping News, No 11.

Peters, E. E. (1994). Fractal Market Analysis. Wiley finance edition, NY.

Randoy, T., Down, J., \& Jenssen, J. I. (2003). Corporate Governance and Board Effectiveness in Maritime Firms. Maritime Economics \& Logistics, 40-54. http://dx.doi.org/10.1057/palgrave.mel.9100059

Rousos, E. P., \& Lee, B. S. (2012). Multicriteria analysis in shipping investment evaluation. Maritime Policy and Management, 39, 423-442. http://dx.doi.org/10.1080/03088839.2012.690080

Scarsi, R. (2007). The bulk shipping business: market cycles and shipowners' biases. Maritime Policy and Management, 34, 577-590. http://dx.doi.org/10.1080/03088830701695305

Stokes, P. (1997). Ship finance, LLP, London.

Stopford, M. (1989). Will the shipbuilding capacity be available and at what price? Outlook, (March).

Stopford, M. (2009). Maritime Economics (3rd ed.). Routledge, London. http://dx.doi.org/10.4324/9780203891742

Syriopoulos, T., \& Tsatsaronis, M. (2011). The corporate governance model of shipping firms: financial performance implications. Maritime policy and Management, 38, 585-604. http://dx.doi.org/10.1080/03088839.2011.615867

Tvedt, J. (2003). Shipping market models and the specification of freight rate processes. 
Maritime Economics \& Logistics, 327-346. http://dx.doi.org/10.1057/palgrave.mel.9100085

UNCTAD. (2012; 2007). Maritime transport review, yearly, Genève (downloaded Sept. 2013).

Valentine, V. F., Benamara, H., \& Hoffmann, J. (2013). Maritime transport and international seaborne trade. Maritime Policy and Management, 40, 226-242. http://dx.doi.org/10.1080/03088839.2013.782964

Volk, B. (1984). Shipping Investment in Recession. Institute of Shipping Economics, Bremen.

Weatherall, J. O. (2013). The Physics of Wall Street: a brief history of predicting the unpredictable. Houghton Mifflin Harcourt, Boston, NY.

Zannetos, Z. (1966). The Oil tank ship rates. MIT.

\section{Appendix}

The Figure below represents the curves of the normal and Cauchy distributions.

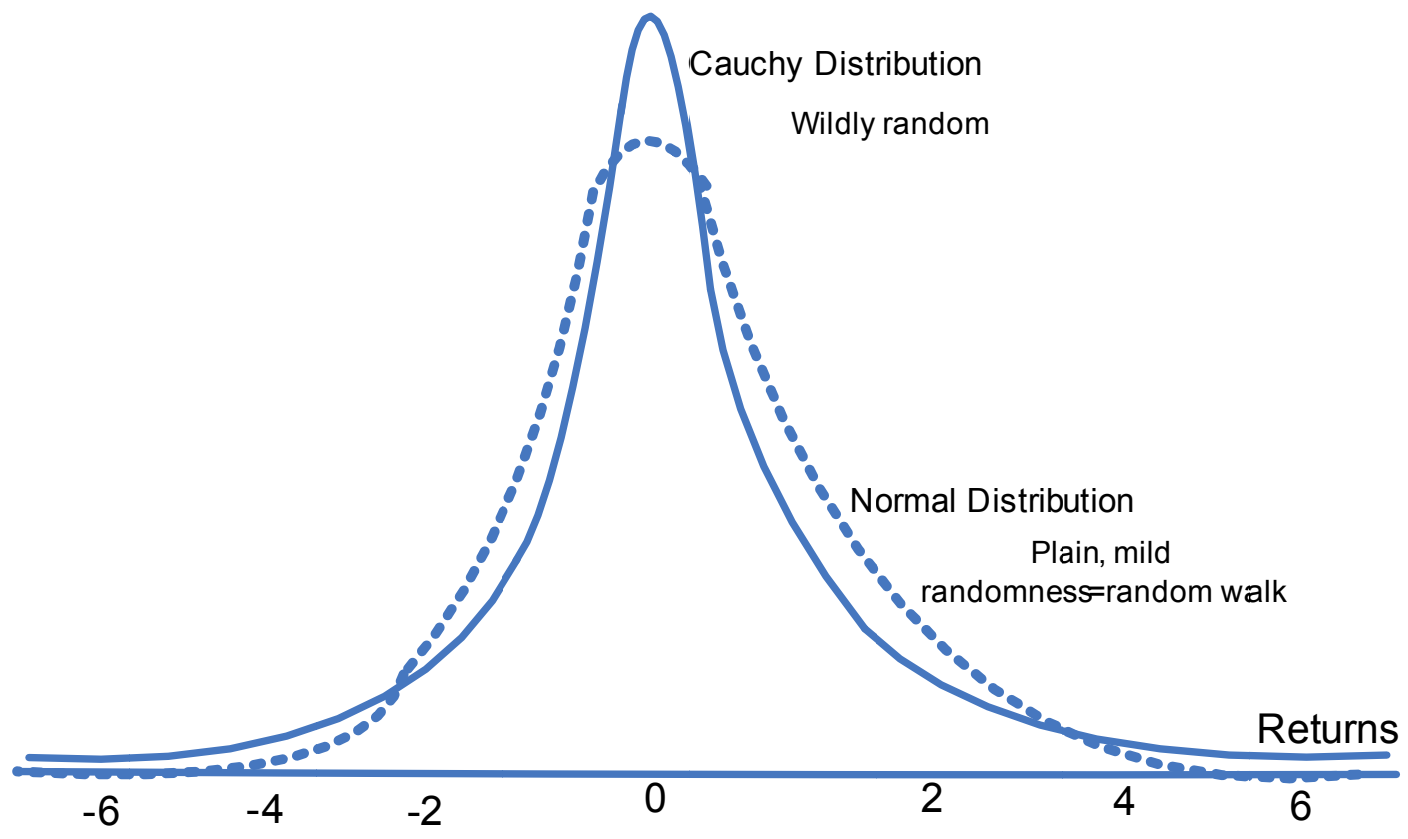

It shows that all random processes are not governed by the normal distribution. The Cauchy distribution (fat-tailed) - solid line - is thinner and taller than the normal distribution - dotted line - round its central values, but tails fall off more slowly. Events far from the center of the distribution are more likely than the normal distribution would predict. These phenomena are wildly random as experience shows with many major extreme events. As Weatherall (2013) argued, the normal and log-normal distributions are insufficient to capture the statistical properties of markets. Rates of return have fat tails. If markets are Levy-stable distributed, 
then variance is infinite and, most importantly, certain standard statistical tools are inadequate to analyze them. Shipping gave two values of alpha: 1.09 or approximately equal to 1 (days) and 1.47, or approximately 1.5 (months), each pointing to Cauchy and Levy-stable distributions in between, but not to a normal distribution (alpha=2). An important corollary is that these alpha coefficients, though for the same industry and the same period, are different, depending on the nature of data (whether taken by the minute, the day, or the week, etc.).

\section{Copyright Disclaimer}

Copyright for this article is retained by the author(s), with first publication rights granted to the journal.

This is an open-access article distributed under the terms and conditions of the Creative Commons Attribution license (http://creativecommons.org/licenses/by/3.0/). 